\title{
家庭用電気洗たく機しぼりローラ軸受の
}

\section{摩 擦についで}

（第 2 報）グリース潤滑時の特性

\section{1.はしがき}

第 1 報に捈いて数種の合成樹脂製軸受を，しぼりロー ラ軸受に使用した場合の無潤滑時の摩擦特性を論じ，な かでもポリアセタール樹脂に属するデルリンがすぐれた 性能を有することが判明した。しかし実際に使用するに 当っては。無潤滑で用いるよりも潤滑剂を用いる方が有 利であることはいうまでもない，無潤滑状態というのは 潤滑剂のなくなった最悪の状態に相当する。それゆえ， 本報ではグリース潤滑時の性能を, 前報同様静荷重トル クレバー式嵮受試験機を用いて実験的に検討する.

\section{2. ク゚リース瑇の影響}

電気洗たく機ということからして, 油潤滑は困難であ るので，グリース潤滑を行なうこととした，そのために 軸受中にグリースをためて扔く部分を必要とする．第 1 報第 7 図（a）に示した妨す及付試験軸受の接触幅を拡 ゲ，第1図に示すように「キ」の字型に溝を注り，接触 部の総面積が第 1 報第 7 図の軸受の接触面積とほぼ等し くなるようにした: ただし 試験軸受に抢いては機械加 エによって溝を切った。

以上のようにグリース溝 を付けたので, この溝が無 潤滑時の摩擦特性にわるい 影響を与えては困る。この 心配のあるなしをしらべる

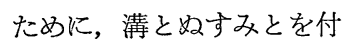
けたデルリン朝受とぬすみ のみ付けたものとを以前と 同じ条件, すなわち $30 \mathrm{~kg}$,

会中島㿽 男 $^{* *}$

$30 \mathrm{rpm}$ で 3 日間連続回転で試験して比較した。実験装 置および方法の詳細は第 1 報に叔けると同じである，実 験結果を第 2 図に示した。この図の二つの結果を比較す
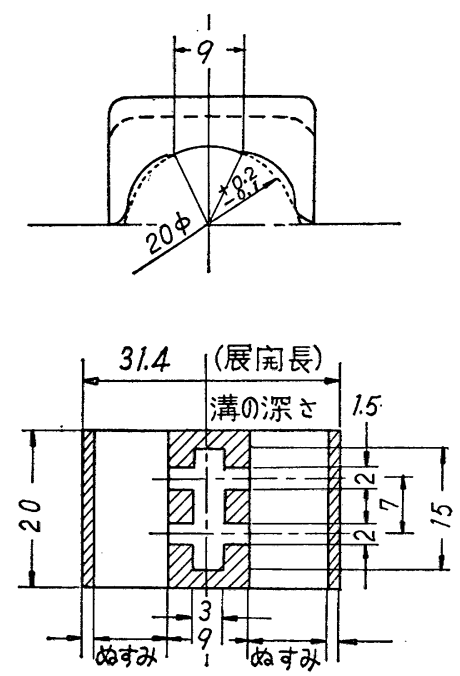

（第1図）グリース溝とぬすみとのあ る軸受の形状
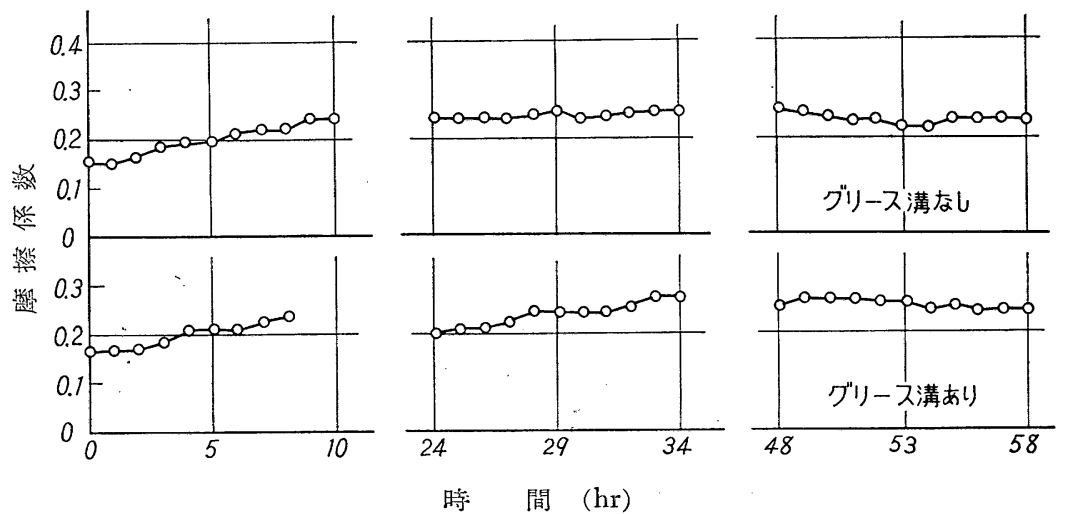

（第2図）グリース㩐の無潤滑特性に扎よぼす影響

* Frictional Behavior of Squeezing Roller Bearing of Electric Home Washers. Part 2: Behavior When Lubricated with Greases.

** K. Nalkajima, Member. 方阪府立大学工学部 
ると，多少の差異はあるにしても，全体としてみればほ

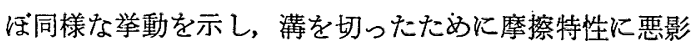
響を打よぼす心配のないことが判明した。

ついでに使用中万一非常に大さな過負荷がかかった場 合を考虑して，溝とぬすみとの付いた軸受に $70 \mathrm{~kg}$ の荷
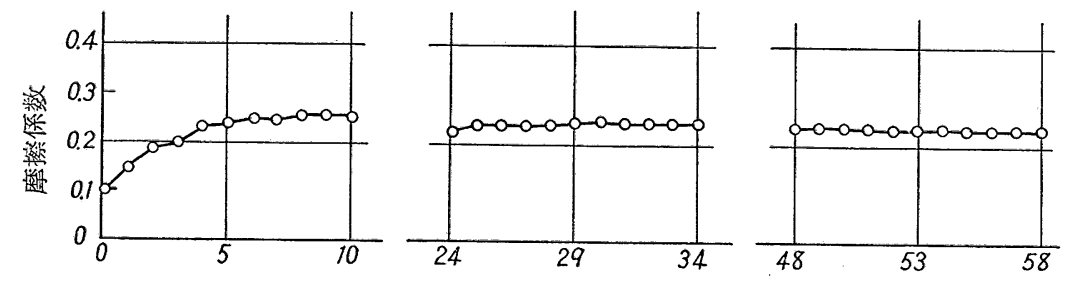

時 間 $(\mathrm{hr})$

（第 3 図）過荷重が無潤滑特性に扣よぼす影響

重をかけて実験した。その結果は第 3 図のようになり, 荷重 $30 \mathrm{~kg}$ のとを比べて同程度あるいは若干低い摩擦 係数が得られた。このことはプラスチックスの摩擦特性 から予想されるところである。 また軸受の当り面がひど くいたむということもなかった．したがって相当な過負 荷に耐え得ることが知られた。

\section{3. 供試グリースの選定}

前節の実験により，グリース溝のついた軸受の実用の 可能性が明らかとなったから，今度はグリースをつめた 場合どれだけ摩擦係数が低下するであろらか，またどん なグリースを用いればよいかという点を検討せねばなら ない.グリースにはいろんな種類のすのがあるが，洗た く機軸受として用いる場合に必要な性質としては, 耐水 性, 耐酸化性, 安定性, 而荷重性, 防銹性などが考兄ら れる。耐水性からいうと,ナトリゥム拉よびマグネショ
ムせっけん基グリースは，水に触れると溶解し去るから 不適格で，それ以外のるのを使用すべきである。しかし 従来不用意にもこの種のグリースが用いられていたので 比較のために試料中に加えた。

以上の諸点を考牕して, 市販のグリース中から下の 15 種を選んだ。グリースの種 類と以下本文中に用いる記 号とを表示すれば，第 1 表 を得る。をたこれらのグリ 一スの特性の測定值の一部 を第 2 表 (メーカのデータ による）に示した。ただし 性質不明の方のは省略し た. グリース Fは $E$ の原色 のものである.
（第 1 表） 供試グリースの種類

\begin{tabular}{|c|c|}
\hline$A, B, C$ & $\begin{array}{l}\text { カルシゥムせっけん基ベアリング用グリー } \\
\text { ス }\end{array}$ \\
\hline$D, E, F$ & リチゥムせっけん基万能グ リース \\
\hline$G, H, I$ & リチゥムせっけん基万能グリース \\
\hline$J$ & リチゥムせっけん基グリース \\
\hline$K$ & カルシゥムせっけん基極圧グッース \\
\hline$L$ & マグネシゥムせっけん基一般用グリース \\
\hline$M$ & アルミニゥムせっけん基モビールグリース \\
\hline$N$ & ナトリゥムせっけん基万能グ リース \\
\hline$O$ & ナトリゥムせっけん基カップグリース \\
\hline
\end{tabular}

\section{4. 連続回転試験による潤滑性能の比較}

第 1 図に示した溝と奴みついたデルリソ軸受の溝 中に，前節の各種のグリースを手で充てんし，ついでに 軸受内面全体にかるく塗りつけておく。この試験軸受を

（第2 表） 供試 グทースの性質

\begin{tabular}{|c|c|c|c|c|c|c|c|c|}
\hline \multirow{2}{*}{ 種 類 } & \multirow{2}{*}{ 外 観 } & \multicolumn{2}{|c|}{ 古上5度 } & \multirow{2}{*}{$\begin{array}{l}\text { 滴 点 } \\
\left({ }^{\circ} \mathrm{C}\right)\end{array}$} & \multirow{2}{*}{$\begin{array}{c}\text { 兏 分 } \\
(\%)\end{array}$} & \multirow{2}{*}{$\begin{array}{l}\text { 水 分 } \\
(\%)\end{array}$} & \multirow{2}{*}{$\begin{array}{c}\text { 粘 㢇 } \\
\text { (鉱油分) } \\
\text { RW } 50^{\circ} \mathrm{C}\end{array}$} & \multirow{2}{*}{$\begin{array}{c}\text { 使用温度 } \\
\text { 籍 } \\
\left({ }^{\circ} \mathrm{C}\right)\end{array}$} \\
\hline & & 60 回 & $10^{5}$ 回 & & & & & \\
\hline$A$ & 黄褐色乾こう & 181 & - & 102 & 2.82 & 1.2 & 180 & $-10 \sim 70$ \\
\hline$B$ & " & 250 & - & 103 & 2.48 & 1.1 & " & " \\
\hline C & " & 290 & - & 96 & 2.05 & 0.9 & " & " \\
\hline$D$ & 紫色軟と 5 & 324 & 390 & 182 & - & 痕跡 & 250 & $-30 \sim 150$ \\
\hline$E$ & $" 1$ & 269 & 370 & 187 & - & " & " & " \\
\hline$F$ & 灰色乾乙 5 & " & " & " & - & " & " & " \\
\hline$G$ & 黄褐色軟こう & 370 & - & 155 & 0.98 & " & 350 & $-5 \sim 150$ \\
\hline$H$ & " & 325 & - & 160 & 1.10 & " & " & " \\
\hline$I$ & " & 280 & - & 170 & 1.21 & " & " & " \\
\hline K & " & 325 & - & $>260$ & - & - & 450 & - \\
\hline$L$ & 橙色軟乙 5 & 243 & - & 178 & 2.34 & 痕跡 & 140 & $-5 \sim 120$ \\
\hline
\end{tabular}



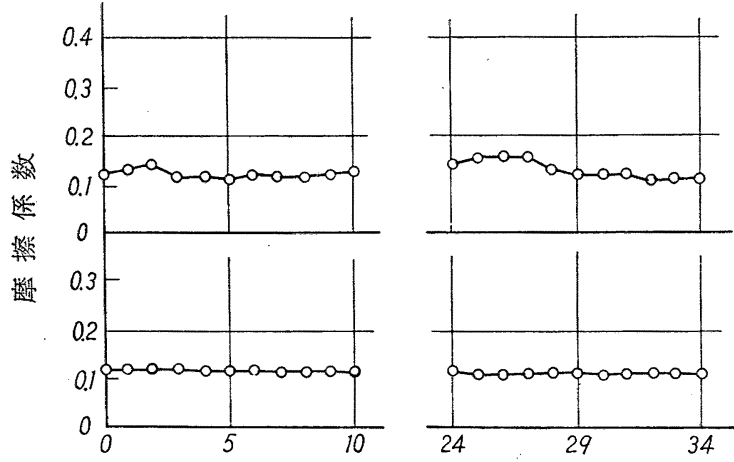

時 間 $(\mathrm{hr})$

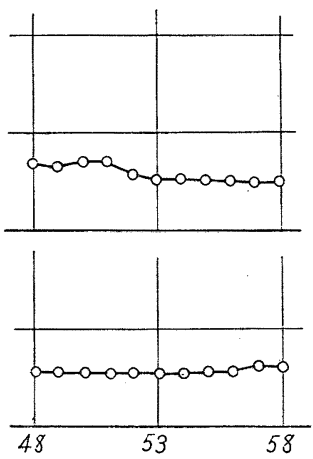

（第 4図）グリース $A$ K関する 2 回の実験結果の比較

のバラッキはあるにしても この種の実験としてはかな りょく一致している。 それ ゆえ結果の再現性抢よび信 頼度に対してある程度見当 をつけることができる。な 扮この 2 回の実験時の室温 は約 $30^{\circ} \mathrm{C}$ と約 $10^{\circ} \mathrm{C}$ とで 温度の影響の入っているこ とを付記する。

実験結果のいくつかを第 5,6 図に示す。第 5 図の

用いて，第 2 節の無潤滑試験に括けると同じ実験装置お よび方法によって 3 日間の連続回転試験を行なった．実 験条件も前同様 $30 \mathrm{~kg}, 30 \mathrm{rpm}$ である.

まず $A, B, C$ の 3 種のグリースに対して各 2 回の赛験 を行なった、グリース $A$ についての前後 2 回の結果を第 4図に示した，この図において前後 2 回の結果は, 多少
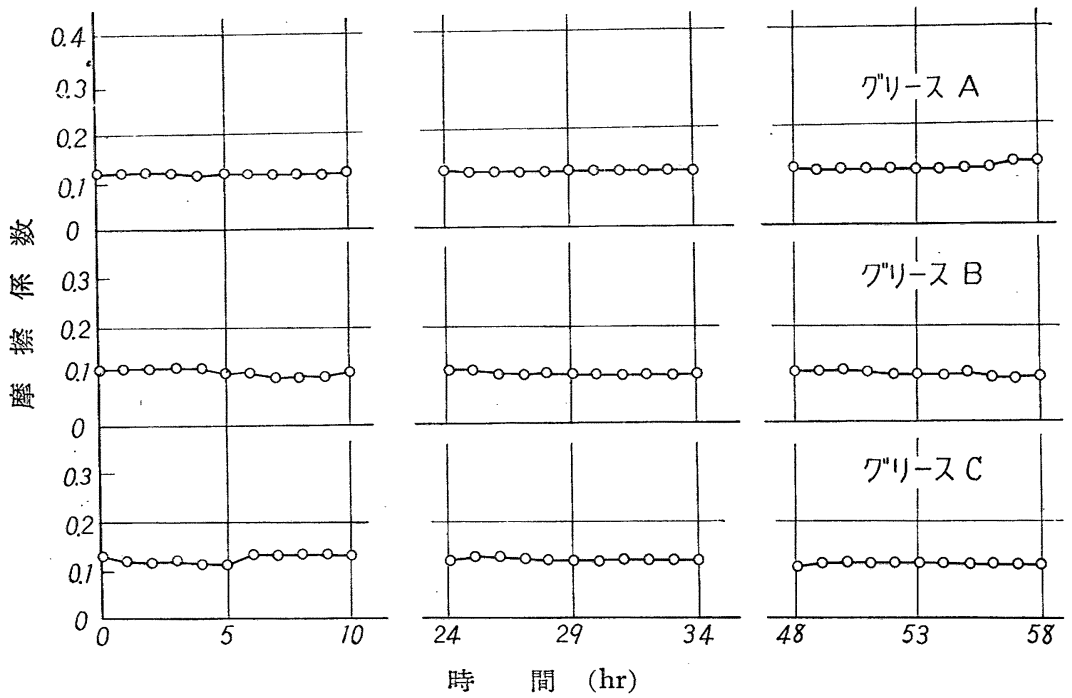

（第 5 図）カルシゥムせっけん基ベアリング用グリースに 扎けるちょう度の影響
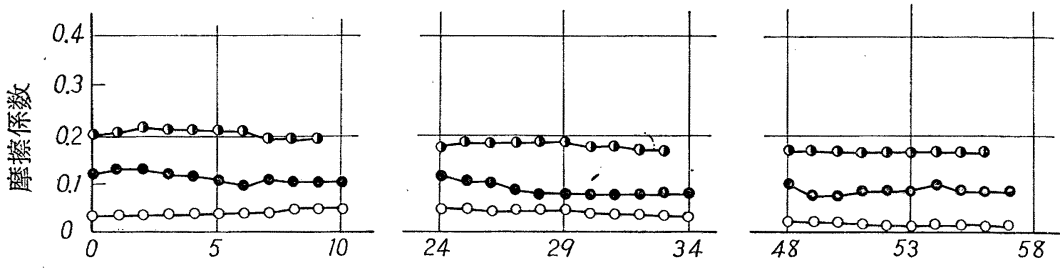

時 間 $(\mathrm{hr})$

$\bigcirc$ グリース $G$, グリース $H$, グリース $I$

（第6図）リチュウムせっけん基万能グリースに扣けるちょ5度の影響
3 種のグリースはいずれもカルシゥムせっけん基のもの で，鉱油粘度も同じであるが，ちょ5度だけが 3 段階に 変化している．第6図の 3 種のリチゥムせっけん基グリ 一スも同様である。しかし摩擦係数とらょう度との関係 はこれら両者では事情をまったく異にし，第6 図ではち よう度の低い，すなわらかたいグリースが大きな摩擦係

数を示しているが，第 4 図 ではちょう度の影響はそれ ほど顕著ではない。したが ってグリースの選定には, 単にその種類のみならず, ちょう度を考慮する必要が ある、な打通常グリースは 夏期にはちょ のを，冬期にはちょう度の 高いものを使用するのがよ いとされているが，このし ぼりローラ軸受ではこの種 の使いわ将をる必要のな いことが第 4図の結果から 知られる。

実験した15種類のグリー スについて，第 5,6図と 同様な結果が得られるが, いらいら図示することは省 略した. しかしこれらの結 果をみると, 時間の経過と ともに摩擦係数の徐々に減 少するもの, 徐々に増加す るもの，ほぼ一定なものな どがあるが，全般的にいえ 
は安定した潤滑状態を示し，この点だけからすればとく に不都合なものはなかった。

つぎに摩擦係数の絶対值には、すでに記した通り，かな りのちがいが認められる．時間対摩擦係数曲線を大部分 省略したので, とくに意味のありそうな実験開始時の摩 擦係数と定常状態の摩擦係数との值を第 3 表に示した。 定常状態の縻擦係数の值が 2 重に入っているのは, 実験

（第 3 表） 摩擦係数の测定値

\begin{tabular}{|c|c|c|c|c|c|c|}
\hline \multirow{2}{*}{ 種類 } & \multicolumn{3}{|c|}{ 運転開始時の摩擦係数 } & \multicolumn{3}{|c|}{ 定常状態の摩擦係数 } \\
\hline & 第1日目 & 第2日目 & 第3日目 & 第1日目 & 第2日目 & 第3日目 \\
\hline$A$ & 0.125 & 0.115 & 0.11 & $\left\{\begin{array}{c}0.111 \\
0.125\end{array}\right.$ & 0.12 & 0.115 \\
\hline$A$ & 0.10 & 0.10 & 0.11 & 0.105 & 0.105 & 0.115 \\
\hline$B$ & 0.12 & 0.11 & 0.11 & $\{0.10 /$ & 0.10 & $\{0.10 /$ \\
\hline$B$ & 0.135 & 0.13 & 0.145 & 0.125 & 0.105 & 0.105 \\
\hline$C$ & 0.12 & 0.115 & 0.115 & 0.115 & 0.11 & $0.11 /\}$ \\
\hline$C$ & 0.115 & 0.14 & 0.135 & 0.115 & 0.11 & 0.10 \\
\hline$D$ & 0.11 & 0.10 & 0.085 & 0.095 & 0.05 & 0.065 \\
\hline$E$ & 0.10 & 0.09 & 0.12 & 0.075 & 0.105 & 0.09 \\
\hline$F$ & 0.14 & 0.10 & 0.10 & 0.10 & 0.10 & 0.09 \\
\hline G & 0.035 & 0.045 & 0.02 & {$\left[\begin{array}{l}0.035 / \\
0.045\end{array}\right.$} & $\left\{\begin{array}{c}0.04, / \\
0.03\end{array}\right]$ & 0.015 \\
\hline$H$ & 0.12 & 0.115 & 0.10 & 0.105 & 0.08 & 0.085 \\
\hline$I$ & 0.20 & 0.175 & 0.165 & 0.19 & 0.17 & 0.165 \\
\hline$J$ & 0.08 & 0.095 & 一 & 0.085 & 0.095 & 一 \\
\hline$K$ & 0.045 & 0.015 & 0.04 & 0.03 & 0.05 & 0.065 \\
\hline$L$ & 0.11 & 0.12 & 0.07 & 0.105 & 0.08 & 0.055 \\
\hline$M$ & 0.095 & 0.015 & 0.04 & 0.03 & 0.05 & 0.065 \\
\hline$N$ & 0.12 & 0.105 & 0.125 & 0.145 & 0.13 & 0.115 \\
\hline$O$ & 0.06 & 0.04 & 0.03 & $0.045^{\circ}$ & 0.03 & 0.03 \\
\hline
\end{tabular}

中 2 種の定常状態を示したことを意味する。（第4図参 照)

第 3 表の值から摩擦係数の大小によってつぎのように 分類してみるただしこの分類はまったく便宜的なるの で, 理論的な意味はない.

(1) 摩擦係数が 0.05 以 下のもの $\cdots \cdots \cdots \cdot \cdots, K, O$

(2) 摩擦係数が $0.05 \sim$ 0.10 のあの

$\cdots \cdots D, E, H, J, L$

(3) 摩擦係数が 0.10

0.15 のもの

$\cdots A, B, C, F, M, N$

(4) 摩擦係数が $0.15 \sim$

0.20 のもの .. I

従来使用されていたグリ ( 無潤滑, 荷重 $70 \mathrm{~kg}$
一ス○は非常に低摩擦で，むし軸受部に水分の浸入する おそれがなく，グリースの変質の危険がなければこれで 十分である.しかしこれらの点について心配があれば， ナトリゥム叔よびマグネシゥムせっけん基グリースは避 けた方がよく，また長期間の使用に耐えるに必要な各種 の添加剂入りのものを使用すべきである.

これらを除外すると，好成績を示したのは主としてり チゥムせっけん基グリースである。これらのグリースに

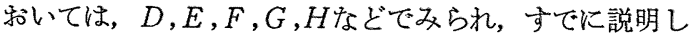
たようにグリースのちょ 5 度が問題で，本実験程度の負 荷条件 $\left(27 \mathrm{~kg} / \mathrm{cm}^{2}, 1.9 \mathrm{~m} / \mathrm{min}\right)$ では, むしろちょ 5 度の高いやわらかいグリースの方が低摩擦を示してい る（第 3 表，第 6 図参照），一方カルシゥムせっけん基 グリース $A, B, C$ ではらょ5度の影響は顕著ではない が,これはちょう度のレベルが $A \sim C$ では 181〜290で あるのに対し，D〜Iでは 269〜370 であること, 基油 の粘度がそれぞれ 180，250３50 であること， $A \sim C$ は1\%前後の水分を含んでいることなぞによるものと想 像される、な特カルシゥムせっけん基グリース $K$ あ良い 成績を示した. このグリースのらょ 5 度はグリースCの ちょう度よりやや高い程度であるが, 基油の粘度もらが うし，各種添加剂を含んでいるので，これはもしろ極圧 添加剤の入っているためであろうと思われる. しかしこ の現象を解明するには，もっと基礎的な研究が必要と思 われるので，ここではこれ以上深くは立ち入らないこと にする.

なおグリース $D \sim F$ 系列と, グリース $G \sim I$ の系列

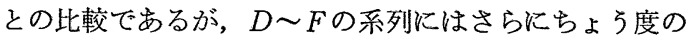
高いGに対応するものがあるはずであったが，あいにく 実験時には入手できなかったので，実験から割愛した。 しかし実験結果を検討してみると，もしこの種のグリー スが入手できて実験に加えることができて执れば，非常
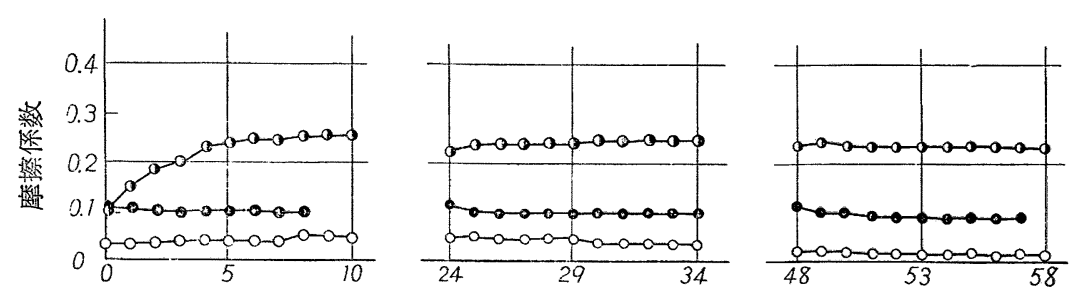

時 間 $(\mathrm{hr})$

グทース $G, \bigcirc$ グทース潤滑，荷重 $30 \mathrm{~kg}$, グリース潤滑荷重 $70 \mathrm{~kg}$,

（第 7 図） 過荷重がグッース潤滑特性におよぼす影響 
に良い成績を示したのでは なかろらかと推察される。

もっとも良い成績を示し たグリースGについて荷重

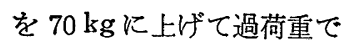
実験した結果を第 7 図に示 した、第 7 図には同じグリ ースを用いた荷重 $30 \mathrm{~kg}$ の ときの結果と, 第 2 節で得
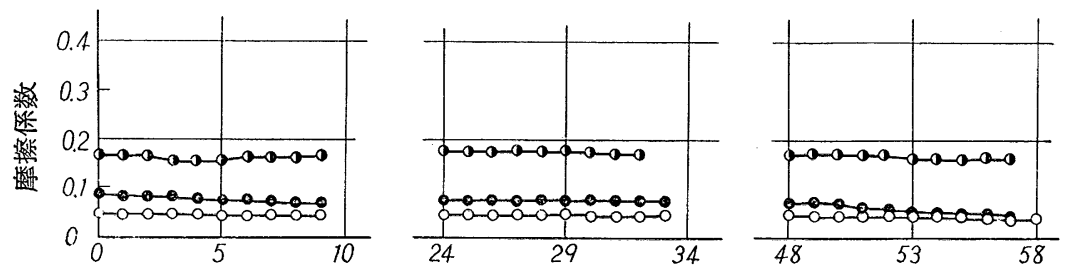

時 間 (hr)

$\bigcirc$ グทース $G$, グリース $K$, グทース $B$

（第 8 図） 3 種のグリースによる潤滑時の間欠回転試験結果

られた無潤滑 $70 \mathrm{~kg}$ ときの結果とをあわせ示してあ る.これらの結果を比較すると, 荷重 $70 \mathrm{~kg}$ ではグリー スを用いても，30 kg のときに比べて摩擦係数の増加す ることは覚悟せねばならない，しかし無潤滑時に比べる と,グリースの潤滑効果の著しいことも知られる. この 実験は単に過荷重での挙動をしらべるのが目的であるか ら, 常用最大荷重が $70 \mathrm{~kg}$ の場合には改めてちょ5度の 影響をしらべることが必要であろう。

\section{5. 間欠回転試験による潤滑性能の比較}

しぼりローラ軸受の実際の使用状態は決して連続回転 ではないが, 第1 報に和いて判明したように, 連続回転 でもって間欠回転時の性能を推定することができる。乙 かし以上の結論は無潤滑時について得られたものであ る.一方本報ではグリース潤滑時を論じているので, 念 のため $B, G, K 3$ 種のグリースに対し間欠回転による比 較実験を行なった。ただ第 1 報とことなり，測定は毎 時間行なった。

実験結果は第 8 図に示した通りで, 全般的にいって摩 擦係数は連続回転に和仢るよりもやや高目に出ているが その值の大小の順位や, 運転時間に対し, 安定した状態 を示している点などは, 連続回転によって得られた結果 とよく似た摩擦特性が得られた。 したがって連続回転に よって間欠回転時の摩擦特性を推測でさることは, グリ 一スの存否には無関係であるという結論が得られた.

\section{6.むす び}

以上の実験結果を総合すると, 第 1 図に示した形状の
グリース溝およびぬすみのついたデルリン製軸受を，適 当ならょう度の各種添加剂入り高級グリース（たと衤ば

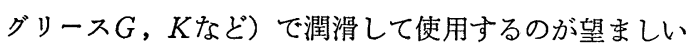
との結論が得られる.

結論をやや詳細に列記すると下のようになる.

（1）軸受のみかけの接触面積を等しくして括けば, グリース溝を切っても, 無潤滑時の摩擦特性には悪影響 を特よぽさない。

（2）デルリンは無潤滑でもかなりの過荷重に耐え, 摩擦の值もとれほど大きくはならない.

（3）グリースはリチゥム，おるいはカルシゥムせっ けん基の添加剂入り高級グリースの中から適当ならょ5 度のものを選ぶ必要がある.

（4）潤滑時の実験結果の再現性はそう悪くはない.

（5）グリース潤滑時過負荷になってもグリースの効 果は残るが, 摩擦はやや増大する.

（6）グリース潤滑時の摩擦挙動の比較は, 連続回転 による実験結果から推定することがでさる。

な拉，実用に供するのに未解決で残っている問題とし て,グリースの安定性の問題があるが, 普通はリチゥム せっけん基グリース, その他の高級グリースには酸化防 止剂その他の添加剂入りのものが多く, 長期間にわたっ ての安定な作動を期待してよいものと思われる.

\section{参考文献}

1）中島条男: 瀻維機械学会誌, 17, 146 (1964)

2）たとえばC. Rubenstein: Proc. Phys. Soc. B, 69, 921 (1956) 